\title{
Toward a Model of Just Tourism: A Proposal
}

\author{
Oliver Mtapuri ${ }^{1}$ and Andrea Giampiccoli ${ }^{2, *}$ (i) \\ 1 School of Built Environment and Development Studies, University of KwaZulu-Natal, Howard College \\ Campus, Private Bag X54001, Durban 4000, South Africa; mtapurio@ukzn.ac.za \\ 2 Department of Hospitality and Tourism, Ritson Campus, Durban University of Technology, P.O. Box 1334, \\ Durban 4000, South Africa \\ * Correspondence: andrea.giampiccoli@gmail.com
}

Received: 27 February 2020; Accepted: 17 March 2020; Published: 26 March 2020

\begin{abstract}
Inequality is growing within and between countries. Tourism is a growing sector affecting lives, with a vibrancy of its own and malleable structures that can benefit a majority, if social justice and equality are the goals. Cooperatives are one of these structures, and have the potential to drive a development trajectory that delivers a just tourism. We define just tourism as a form of tourism that delivers the most benefits to its members-for themselves and by themselves-representing a form of accumulation from within. This article is based on secondary data and is a conceptual paper. It posits a coop hotel model, which harnesses the hope of spreading the cooperative model for its finer qualities of providing job security to workers, happiness, democratic participation, decision making functions, self-governance, empowerment, openness, retention of capital within the community, the pursuit of both economic social goals, resilience, and importantly, the emphasis on community contribution and matters of sustainability. Community-based tourism and cooperatives have interlocking values such as local control, local/self-management, and being steeped in the local context. The coop hotels model, which is the main contribution of this article, suggests the creation of mother hotel coops, with coop sisters and coop children in pursuit of social justice for a just tourism.
\end{abstract}

Keywords: tourism; cooperative; community-based tourism; equality

\section{Introduction}

It is from the 1970s that neoliberalism in the Global North changed the political economy of 'global capitalism' worldwide (Boden 2011). Specifically in the Global South, "neoliberalism has had a profound impact in the relation to increase in levels of inequality and poverty, new forms of accumulation by dispossession such as privatization of the commons and the rise in power of finance capital at both the national and international level." (Boden 2011, p. 83). However, the Global South was not the only to suffer inequality, the impact has been felt in both developed and developing worlds, and between and within countries. The "global social stratification is more visible today than ever before. The gap between rich and poor citizens, within both developed and developing nations is also growing." (Zajda 2011, p. 147). This wealth gap between a few people living mostly in the North and a large amount of people living in the South should be seen as "a structural divide, not just a matter of a lag in the South's catch-up" (Hunter Wade 2004, p. 583; Giampiccoli and Saayman 2016). At the same time, globalization 'is almost exclusively economic' to the exclusion of other international agents, which formed the earlier internationalist ideal and proposed that the idea of 'one world' meant an international agenda of peace, social justice, human rights, environmental protection, mutual understanding, education, and cultural exchange. This is important 'and suggests that the experience of globalization is one-sided and in the interests of the powerful.' (Ife 2002, p. 141). By implication, the weak lose out and are assigned to conditions of disadvantage and powerlessness in a one-sided global world. The sector is not immune to health pandemics. 
Tourism is susceptible to the effects of pandemics because it is based on the interaction among people (UNWTO 2020a). As a result, tourism is one sector that has borne a lot of the impact of Coronavirus (COVID-19). The United Nations World Tourism Organisation (UNWTO 2020a) mentions that the COVID-19 pandemic is a big challenge for the sector and requires reliable and impeccable leadership that will prioritize tourism during the recovery phase. Many countries are already enduring the negative consequences of the COVID-19 pandemic. For example, in Thailand, the collapse of the Chinese market has provoked a sharp drop in business as many flower sellers, drivers of the 'red car' minibuses, traditional dancers, and others have reported a reduction in their monthly income by half, while the informal association of tour guides in Thailand is of the view that 25,000 people have lost their jobs (Head 2020). These are mostly small businesses that do not often have adequate funding to survive, but are vulnerable to the vicissitudes of the COVID-19 pandemic. In the USA, it is estimated that the city of Louisville alone lost an estimated $\$ 57.6$ million because of cancellations occasioned by COVID-19. As such, there is a worry around the world about the sector's growth prospects in many countries worldwide. Thus, the UNWTO (2020b) revised its growth prospects for 2020 for international arrivals to negative $1 \%$ to $3 \%$, which estimates a loss of US\$ 30 to 50 billion in international tourism receipts. Before the COVID-19 outbreak, the UNWTO predicted a positive growth of $3 \%$ to $4 \%$ for this year. There is a need for political and financial support for the sector during the recovery stages in affected economies (UNWTO 2020b). It can be added that these unfortunate circumstances can be used as an opportunity to reorganize and reconfigure the tourism sector toward a more redistributive and egalitarian status.

There is a need of structural change. To achieve equity, you need to remove market rules that favor the rich: there is equally a need for political influence (nonmarket) so that free markets do not concentrate power ad income-all this invokes the need for international policy, which goes beyond neoliberalism (Hunter Wade 2004, p. 583). There seems to exist a blind and prejudicial defense of neoliberal ideas that do not take into account structural inequalities and any redistributive efforts because redistribution is considered to be creating dependency (Mosedale 2016, p. 9). A similar thought has been observed within the tourism literature that progressive groups that challenge this view are castigated as unscholarly and unqualified because they embrace and acknowledge the life struggles of local people for social justice and equity (Pleumaron 2012, p. 46). Instead, it is argued here that within this context of inequality and quest for social justice, the reconfiguration of the tourism system can contribute toward the realization of an equal society (Giampiccoli and Saayman 2016, p. 3).

Tourism is a vibrant rising sector and is considered as a development tool (Krajnović et al. 2015, p. 79). Tourism has become an important activity in many societies with the potential to enhance economic development and environmental protection (Eraqi 2007, p. 191). The relevance of tourism makes it urgent that it actively contributes to the creation of a more equal and just society. It is important to thrust tourism into the wider political debate that attempts to address issues of poverty, inequality, the environment, and climate change in a globalized world (Pleumaron 2012, p. 6). This is important because there is considerable empirical evidence that shows the negative impacts of tourism on the environment. This also relates to the question of whether or not the negative impacts also affect local communities (Eraqi 2007, p. 191). At the same time, questions are being asked as to whether or not tourism is 'a passport to development', or extending the colonial hegemony and widening the inequalities between developed and developing countries (Pleumaron 2012, p. 16).

Local community involvement in tourism is necessary but rare. For example, from a heritage tourism perspective, it has been indicated that despite "as the 'owner' and custodian of heritage and usually directly impacted by tourism development, local communities seldom have genuine control over the nature and direction of tourism development." (Su and Wall 2014, p. 147). It is argued that community participation is a core factor in sustainable tourism, and their participation in planning is crucial to ensure that most of the benefits are ring fenced for them by them during planning (Ly 2014, p. 250; Salleh et al. 2016, p. 565). Community participation is integral to sustainable tourism (Eshliki and Kaboudi 2012, p. 334). There is a need to integrate community participation with 
tourism development because entrepreneurs and businesses are catalysts for economic development (Salleh et al. 2016, p. 570). Local community participation "in tourism is seen as a positive force for change, and catalyst for development" (Jaafar et al. 2015, p. 9). Community participation can be effective by using a cooperative enterprises model, especially, but not only for workers. Cooperative enterprises are not new in tourism. It should be mentioned here that in 1979, de Kadt (1979), while discussing the case of a cooperatively-run community guesthouse, noted the difficulties of a community-based approach. However, the role of community-based organizations (CBOs) like cooperatives in tourism has yet to be recognized (Aref and Gill 2009, p. 68).

This article is concerned with cooperative enterprises as a model for enterprise development, which it supports. There are other models or types of enterprises such as community controlled enterprises or enterprises with democratic employee stock ownership plans (ESOPs) (see United States Federation of Worker Cooperatives 2007) that are feasible with specific internal regulations and requirements, which strongly support redistributive measures, employee control, and the general holistic distribution of benefits to the community and concern for its well-being. This article specifically uses the hotel sector as an example to illustrate the potential for achieving social justice through enterprise. However, any accommodation establishment, or any other enterprises in the tourism and hospitality sector such as travel agency and restaurant could develop similar models with appropriate adjustments.

This article challenges the dominant discourses in tourism studies in line with Bianchi (2009), who argued that there is a need for a paradigmatic shift in our thinking of tourism that takes into account different worldviews including cultural differences. Within this context, this article proposes a new trajectory whose focus is to, inter alia, decrease inequality and improve the working conditions in an emancipatory way that allows workers and local communities to take control of the tourism industry. The aim of this article is to postulate and articulate a model of 'just tourism', emerging from the finest qualities found in both community based tourism and cooperatives. Its objectives are to unpack the finer qualities in both community-based tourism (CBT) and cooperatives, and to investigate the potential of cooperative enterprises as a model for enterprise development.

This article is a conceptual paper. Gilson and Goldberg (2015) argue that a 'conceptual paper does not have data, as its focus is on integration and proposing new relationships among constructs' (p. 127). This is what this article does by using secondary sources of academic books and journal articles to argue that cooperatives restore the hopes of workers and their communities by offering jobs and income and, importantly, a new pathway to a just tourism. The first stage involved running a Word Cloud in Nvivo version 12. A Word Cloud is a visualization of words in text data where the most commonly used words are larger in size than the less used words to show the trending terms based on frequency of use. This was done to surface the key words necessary for the identification of the finer qualities of CBT and cooperatives. In qualitative discourses, these key words are labelled as codes or themes. A combination of codes in an analytic process makes a category. In the process, the literature review covered issues of cooperatives as a model for enterprise development, neoliberalism and its effects, the role of government, the role of markets and tourism sector in the global milieu as well as various alternative forms of tourism including CBT. Therefore, this conceptual paper aims to add value to the discourse on cooperatives. Gilson and Goldberg (2015) also observe that the "what's new" question characterizes a conceptual paper. This article addresses that question by positing and arguing for new Coop Models of Mother, Sister, and Children Cooperatives. As such, no new primary data were collected from the field.

\section{Literature Review and Methods}

In the past thirty years, neoliberalism has been generating huge profits for venture capitalists, investment institutions, and multinational firms, thereby creating a clique of global super rich while increasing the inequalities in health, life chances, and incomes within and across countries since the Second World War (Hall et al. 2015, p. 9). The impacts of neoliberalism go beyond mere economics 
as they also negatively affect governments and communities. For instance, government structures and services have been dismantled to be replaced by market-driven, private sector-driven approaches accompanied by a decline in the social fabric of the community (Sharpe et al. 2016, p. 5). The common qualities of current capitalism — captured in the blanket term 'neo-liberalism' — can be readily identified following Rojek's (cited in Britton 1991) four main characteristics of the organization of leisure in modern capitalism: privatization, individuation, commercialization, and pacification. A hegemonic neoliberal discourse is present (Cox 1996a, 1996b; Gosovic 2000; Peet 2002). In tourism studies, a cultural, economic, and political hegemonic milieus is noted (Giampiccoli 2007; Giampiccoli and Mtapuri 2012). This indicates that development should go beyond redistribution because "it is not sufficient to redistribute wealth or resources and assume all is just, because the oppressive structures that contribute to inequality would remain intact." (Sharpe et al. 2016, p. 7). This implies that structures that favor some people (especially the rich) over others should be dismantled and measures that reduce inequality should be proactively instituted as markets alone are incompetent to address inequality and it is not the sole prerogative of the private sector to address. As such, any forms of redress and redistribution to reduce inequality have to be state-led, only if the state has the political will to do so.

This article argues that while redistribution is a central issue to advance, a holistic radical restructuring of the global system as a whole (and the tourism sector within it) is the ultimate goal. Leftist oriented policies inclined to a socialist form of 'democratic participatory socialism' (Devine 2002, p. 5; see also the issue of Science \& Society, 2002), and participatory planning and self-management should address inequality through redistribution (Kotz 2008, p. 5). In this form of socialist oriented participatory democracy, national planning should be counterbalanced by effective local control, and this entails decentralizing economic decisions to the local or regional level for maximum participation (as opposed to the old-style central planning that was overly centralized) ((Kotz 2008, p. 5); on similar issue on the relation between national and grassroots planning national and local, see also (Dugger 1987, p. 98)). This is in line with Marx's argument for "workers' self-governance and self-management" in a post-capitalist society (Elliot 1987). Central government should not be abandoned, but should become supportive of decentralization and guarantee the control of key sectors such as energy, education, health, and the advancement of policies that favor redistribution, protecting disadvantaged and minority groups and balance between geographic areas.

The tourism sector is indeed, "a commercial sector that operates within a global neo-liberal market economy." (Chok et al. 2007, p. 144). As such, in tourism, there is often inherently hidden inequality and exploitation. Bianchi (2009) observes that the emphasis in tourism has been on the economic and cultural transactions without exposing the material deprivations and inequalities generated by tourism through the exploitation of workers and poor working conditions in destinations (p. 487). Therefore, tourism contributes to social inequalities (Cole and Morgan 2010, p. XV; Giampiccoli and Saayman 2016). This is made worse by the fact that conventional mass tourism is not concerned with matters of equitable distribution of tourism outcomes (Saayman and Giampiccoli 2016, p. 149). Various studies have shown the relationship between tourism and issues of inequality such as in Nicaragua (Reye 2011), Mexico (Manuel-Navarrete 2012), Lesotho (Braun and McLees 2012), and New Orleans (McClendon 2014). Travelling to "sunny and interesting destinations in faraway places serves to reinforce social and economic inequalities and has clear environmental repercussions." (Sharpe et al. 2016, p. 3). The socio-economic and environmental footprints of tourism are disregarded in pursuit of leisure in sunny and faraway places.

In this context, it can be added that supranational organizations have failed to come up with policies that address poverty and inequality beyond cosmetic changes, names, and terminologies (Mowforth and Mun 2003, p. 267). Notably, forces of privatization and economic deregulation have helped transnational tourism corporations (TNCs) to extend their reach and undermine efforts that support responsible and sustainable tourism (Pleumaron 2012, p. 18). This state of affairs is supported by the liberalization process, which is embraced by international agreements such as the General Agreement on Trade in Services (GATS), which limits the scope for industry regulation 
and for environmental improvement and benefit sharing, prompting the need for profound change (Pleumaron 2012, p. 18). The tourism sector is being used as a strategy for capitalist survival and its sustainability in current times (Fletcher 2011, p. 446; Giampiccoli and Saayman 2016, p. 3). This article argues that different views should be promoted, and not only neoliberal ones.

Hence, measures and approaches to changes in this condition have been proposed in, for example, alternative forms of tourism such as pro-poor tourism (PPT), ecotourism, responsible tourism, and community-based tourism (CBT), and in industry (essentially voluntary) self-regulation, codes of conduct, and the promotion of corporate social responsibility. However, the neoliberal hegemonic milieu makes these alternative strategies circumscribed by, and limited by the hegemony of a neoliberal ideology. In other words, these alternative forms of tourism have been coopted or circumscribed by hegemonic neoliberalism. This is an important issue as transformation attempts and alternative forms of tourism have been jeopardized to meet their social justice and equity goals. In this context, research by Giampiccoli and Saayman (2014) "argues that, while it is true that those alternative forms of tourism development (ET, RT, FTT, and PPT) [ecotourism, responsible tourism, Fair Trade tourism, and pro-poor tourism] have been coopted and re-shaped by the tourism industry within a more general neoliberal philosophy, their origin and development have never been outside the neoliberal framework and the mainstream tourism industry's 'guidance' and control." (p. 1673). Alternative tourism movements that promote societal and ecological transformation for an alternative globalization have been coopted by the industry and neutralized (Higgins-Desbiolles 2008, p. 347). This shows that many alternative forms of tourism have suffered and succumbed under heavy neoliberal pressure. For example, CBT has its origins in alternative development approaches to neoliberal mass/mainstream tourism, but neoliberal forces are re-conceptualizing to conform to neoliberal parameters (Giampiccoli and Saayman 2014, p. 1674), making redistribution doubtful. For instance, Chok et al. (2007) note that “... distributive justice, while a desired outcome, is not an explicit objective of PPT [pro-poor tourism]." (p. 150). There is a shift from the original intention of various alternative tourism forms, thereby dissipating their impact.

In attempts to use tourism to achieve social justice, researches have re-focused on, and are exploiting the characteristics and principles of CBT (Giampiccoli and Saayman 2016; Saayman and Giampiccoli 2016) and justice tourism (Higgins-Desbiolles 2008). Giampiccoli and Mtapuri (2017) argue that "that the use and spread of the progressive CBT principles bodes well for the whole tourism sector as this could provide a platform for the creation of "progressive" companies whose creation is steeped in those principles." (p. 10). In this context, it is the aim of CBT to pursue social justice, local control, and ownership, redistribution of resources, empowerment, and sustainability (Giampiccoli and Saayman 2016, p. 2). For this to happen, CBT should be mainstreamed and internationalized for justice, equity, and sustainability in the tourism sector. It is for this reason that Saayman and Giampiccoli (2016) support the institution of cooperatives to achieve this by also proposing the link between CBT and collective entrepreneurship such as cooperatives. The cooperative business model and CBT should be seen as related, suggested as "Community cooperative is deemed an appropriate business model that can properly address CBT issues" (Mohamad and Hamzah 2013, p. 316) and a CBT manual (Calanog et al. 2012) indicates that community-based ecotourism enterprise (CBET) can be a cooperative. A study (Mohamad and Hamzah 2013) "describes how the cooperative business model successfully created sustainable economic benefits for its local community and reveals how the cooperative effectively managed the local community's economic, environmental and social interests." (p. 316).

There are alternatives to the capitalist model and its market system, which offer a promise of a new dawn, which fosters alternative tourisms and alternative globalizations in order to humanize economic systems such as that done by Hotel Bauen, a cooperative in Buenos Aires (Higgins-Desbiolles 2008, p. 360). In 2014, the cooperative 'experiment' of Hotel Bauen was at risk as "The workers of Buenos Aires Hotel Bauen, who had occupied and renovated an abandoned five star hotel in Buenos Aires after it went bankrupt in the economic crisis of 2001, are now facing a permanent eviction order, after 11 years of successful operation of the hotel as a worker-owned cooperative." 
(Ji 2014). However "After almost 14 years of struggle, the Argentine Senate passed a bill for the expropriation of the Hotel Bauen in favor of the worker cooperative on November 30th, 2016", but was vetoed by the Argentinian President (McNamara 2017). However, in 13 years of its existence, the workers' self-managed Bauen Hotels created 130 jobs with the workers doing major renovations and repairs with very little resources (McNamara 2017). Despite the challenges, Hotel Bauen is currently (as of February 2019) still operating (as noted by the second author of this paper that, being in Buenos Aires for a conference, he personally went to eat at the restaurant in the hotel).

In general, of particular importance for tourism is its impact on communities. To achieve this, community participation in tourism is essential. The impacts of tourism are in the communities so community members enjoy or suffer from it; hence it is necessary for community members to participate in the planning of tourism developments in their communities and to maximize the benefits (Tosun 2000, p. 616). It should be borne in mind that community participation has political, economic, and financial dimensions, although focus has essentially been on the political aspects when the former have the potential to reduce inequality, injustice, and deprivation (Tosun 2000, p. 616). There are cases in which local communities have lost their incomes through tourism when there is a need for balanced development for equity (Pleumaron 2012, p. 22).

Hegemony is complex and has been recreated and renewed and is hotly challenged (Williams 1976, p. 205). Ife (2002) notes that competition in modern society has been taken as both natural and desirable, but this is questionable (p. 134). Two points can be underlined in relation to community development. First, "Challenging the competitive ethic, and basing social and economic structures on principles of cooperation, is an important component of community development." (Ife 2002, p. 134). Second, "The challenge is to extend the cooperative concept beyond the economic (which has been the basis of the most formal cooperatives) to incorporate social, political and cultural dimensions." (Ife 2002, p. 135). Nyerere (1974) had similar thoughts when he mentioned that there is a need to avoid the 'exploitation of man by another' arguing that it is necessary "to work together cooperatively for the common good instead of competitively for individual private gain" (p. 102). Furthermore, this acknowledges that self-reliance "does not imply isolationism, either politically or economically. It means that we shall depend on ourselves, not on others. But this is not the same thing as saying we shall not trade with other people or cooperate with them when it is to mutual benefit." (Nyerere 1974, p. 99). Theories that support existing patterns of ownership and the pursuit of self-interest with the belief that the market knows best are part of the capitalist logic (Lebowitz 2004, p. 22). The next section looks at cooperatives, which are the focus of this article.

\subsection{Cooperatives}

The growth and success of cooperative enterprises is a hidden contemporary matter. For instance, in the USA, not much is mentioned regarding the growing economy of worker cooperatives and democratic workplaces in which thousands work, defying the corporate model of exploitation to create a real economic alternative for workers to have decent jobs (United States Federation of Worker Cooperatives 2007, p. 1). The importance of cooperatives was captured in a study by International Cooperative Allinace (ICA n.d.) that showed that in 2014, cooperatives contributed decent jobs, a sustainable economy, and employed $12 \%$ of the employed population of the G20 countries, involving at least 250 million individuals worldwide in part and full-time employment. The year 2012 was the year of cooperatives mentioning that cooperatives are a reminder to the international community that it is possible to pursue both economic viability and social responsibility (UN n.d.).

Cooperatives are controlled and owned by their members and take different forms and are found in all sectors: this makes them member-driven as they try to balance their pursuit for profit against the interests of their members and communities (UN n.d.). Cooperatives, in general, cherish the following values and principles: self-help, self-responsibility, democracy, equality, equity, solidarity, honesty, openness, social responsibility and caring for others as well as the principles of voluntary 
and open membership, democratic member control, member economic participation, autonomy and independence, education, training and information, cooperation among cooperatives, and concern for community (International Cooperative Alliance (ICA n.d.)). The coop business model is purported to have the following strengths or benefits: a much wider and more equitable distribution of capital within the community; coops keep the capital in the local community rather than siphoning it off to a few centers of financial power as is the case of public corporations; coops 'exemplify the ownership-society' rather than a shareholding class; cooperative governance is more open and democratic than the closed world of the public corporation; and cooperatives pursue both economic and social objectives while public corporations are driven primarily for profit and shareholder wealth; coops provide scope for better market access and market risk reduction including financial benefits from enhanced pricing; improved access to resources; and community building (Mazzarol 2009, p. 40). A report from an Italian case suggests that there are four aspects related to cooperative resilience: resilience due to higher capitalization; the tendency for cooperatives to emerge in times of crisis; the ability of cooperatives to enter new sectors and to provide answers to new sets of needs; and the contribution to the economic and social resilience of the local area (OECD LEED 2014, p. 68). Mills and Davies (2013) succinctly but effectively note the following regarding cooperatives:

Uniquely amongst models of enterprise, cooperatives bring economic resources under democratic control. The cooperative model is a commercially efficient and effective way of doing business that takes account of a wider range of human needs, of time horizons and of values in decision making. It is an approach which works on a very small, and on a very large scale. The cooperative sector is worldwide, providing millions of jobs around the globe. Cooperatives develop individual participation, can build personal self-confidence and resilience, and create social capital. Cooperative institutions create long-term security; they are long-lasting, sustainable and successful (p. 2).

A worker cooperative (WC) is a businesses that is "owned and controlled by the people who work in it" (United States Federation of Worker Cooperatives 2007, p. 1). In other words, "Worker cooperatives are business entities that are (1) owned by their workers, (2) governed by their workers, and (3) operated for the benefit of their workers" (SELC and East Bay Community Law Center(2016, p. 1). It is important to note two issues, first, in conventional businesses there is profit, which in coops is called surplus, which be shared based on hours worked, seniority, or other criteria'; and second, that in WCs, "Worker-control can take many forms depending on the size and type of the business [ ... ]. There are as many ways to make decisions democratically as there are businesses in the world; each worker-owned business creates the structure that is best suited to it" (United States Federation of Worker Cooperatives 2007, p. 1). These issues are relevant as they show that there is no fixed model of a cooperative enterprise, but each context can develop specific criteria of, for instance, surplus distribution and model of worker control.

Matters of ownership and management structures need to be flexible in cooperatives to take into account specific local contexts. Beside the general fundamental guidelines upon which coops are based, flexibility is important. There is no single universal model of a cooperative and the International Cooperative Alliance (ICA) principles are merely guidelines for creating models in various countries and the influence of culture, policies, and laws has also generated various cooperative practices in many countries (OECD LEED 2014, p. 11).

Dastur (2012) concurs with this argument by noting that WCs in the U.S. reflect variations in how their management and administrative functions are executed. In addition, the role and goals of a WC can go beyond mere economic matters to include matters related to what are called "multiple bottom line", which go beyond the money being made but encompass the sustainability of the business, their community contribution, and the longevity and happiness of their members (United States Federation of Worker Cooperatives 2007, p. 2). Their bottom lines include profit, sustainability, worker health, local ownership, job security in bad economic times, and concern for the environment (SELC and East Bay Community Law Center(2016, p. 3). In addition, WCs, 
when properly managed, provide various advantages to workers such as employment and the ability to generate income, control over the way their work is organized, performed, and managed, employment security, a financial and ownership stake in the enterprise, and an opportunity to practice democracy in the workplace (SELC and East Bay Community Law Center(2016, p. 2).

Worker cooperatives are found in many regions and industries in America, such that any business can be owned and controlled by the workers (United States Federation of Worker Cooperatives 2007, p. 1) Workers cooperatives can be especially important in difficult times and regions. From an American perspective, against the backdrop of economic recession and difficulties, and corporate greed "promoting alternative ownership, specifically through worker owned cooperatives, has captured the imagination of community organizers hungry to challenge the existing economy at its heart, and build its replacement in their communities." (Dastur 2012, p. 7).

This article argues that WCs are not inferior to conventional businesses in their performativity and operations. From an American perspective, WCs tend to pay decent and competitive wages and at times above market rates to show that surplus should benefit the workers, they improve job quality, flexibility in working hours to benefit the worker, provide training, and improved quality of products and services to customers (Dastur 2012, p. 8). Moreover, "to economic equity and democratic leadership, cooperatives elevate and advance other values including environmental sustainability and local vitality." (Dastur 2012, p. 8). It has been recently shown that research in various countries about worker coops shows that the failure rate in the short- and medium-term of worker cooperatives is lower than conventional businesses (Olsen 2013). The worker cooperatives shown to be efficient run private firms with their own managerial hierarchy (Fields 2011, p. 83). There is evidence in the literature to suggest that democratic governance and worker participation in the workplace do not impede or lessen productivity and their productivity is comparable to that of conventional firms in the various industries observed (Titzler 2016, p. 8). Titzler (2016) also observes that in spite of a low statistical significance in the regression models, there is evidence to show that cooperatives in the economy have the potential to reduce inequality given the number of cooperatives in the economy and the fact that they grow faster. Given these facts, there is a compelling reason to look at cooperatives as a model for community growth (Tewari 2011, p. 8986). It can be added that the significance and potential of cooperatives and social enterprises is undervalued when they achieve superior socio-economic outcomes better than those produced by conventional firms and other public enterprises (Borzaga et al. 2009). Cooperatives have thrived in many countries of the world, despite the numerous challenges, which they face as they inspire people to a better alternative (SAF-South African Foundation 2003, p. 2). Cooperatives and WCs do have their own weaknesses. The cooperative model has its weaknesses such as the free rider problem, portfolio, horizon, control, and cost problems, but with competent management and worker support, it can be successful (Mazzarol 2009, p. 7). Other challenges associated with cooperatives include expertise, management, financing, and issues of growth (Dastur 2012). These obstacles can be overcome such as in the new generation cooperative (NGC), which is a business model that addresses such problems (Mazzarol 2009, p. 43). The coop business model should be flexible, amenable to each specific circumstance and local context so that the principles of NGC or other forms of coop models can be established in a given coop entity to meet its needs. There is no one size fits all. For example, in relation to the important matter of raising capital, this can be overcome by "issuing memberships to a separate class of 'investor members' who have limited voting rights." (SELC and East Bay Community Law Center(2016, p. 67).

Government and other non-governmental institutions should be the protagonists in supporting and facilitating the cooperative business model. Poverty and inequality invoke the need to rethink how best to address them as markets alone (driven by the private sector) cannot do so (Borda-Rodriguez and Johnson 2015, p. 6). Therefore, market forces cannot redress inequality, but cooperatives bestow the following: more control over markets and benefits accruing to members (redistributive effect), and its structures are democratic and enable articulation of voiceenhance individual and collective agency (Borda-Rodriguez and Johnson 2015, p. 9). 
Despite the challenges, the potential of the cooperative movement is vast, and its role in inclusive development and reducing equality is important. For this to happen, there ought to be an enabling environment supported by legislation, financing, and training in the short-and long-terms (Borda-Rodriguez and Johnson 2015, p. 26). Wearing and Wearing (2016) argue that social justice to eventuate; there is need for strong government for sustainable tourist development. Government cannot do all the work alone. There is a need to elicit the support of local elites who have disproportionately benefited from privatization and deregulation (Bianchi 2002, p. 289). In this sense, the actions of the grassroots movement can directly influence the development trajectories they want and the practices they value. It behooves upon cooperatives to provide that turning point beyond 2020 to provide job security, happiness, and well-being to people given the worsening plight of young people accompanied by global warming (Mills and Davies 2013, p. 2). Cooperatives represent progressive organizations and should be supported in the form of print shops or union hotels in order to scale up their economic footprint (Dastur 2012, p. 21). Despite their challenges, cooperatives have the hope to improve job security, worker happiness, and well-being at scale. Thus, "While the cooperative enterprise is unlikely to solve all the world's economic woes, there is an opportunity for the cooperative movement to promote their unique form of business as a potential 'third way'" (Mazzarol 2009, p. 47). The next section looks at tourism and cooperatives.

\subsection{Tourism and Cooperatives}

There are numerous cooperatives operating in the tourism sector (see, for example, Davolio 2013; Vocatch 2010). For example, in 2013, cooperatives were celebrating as noted:

On 4 December 2013, more than 1000 worker and social cooperatives from the CECOP-CICOPA Europe network involved in activities linked to tourism celebrated the European Tourism Day. The cooperative business model, which is based on values such as self-responsibility, democracy, equality and solidarity, allows to achieve a more sustainable and responsible tourism while combining economic competitiveness with social and environmental needs. (European confederation of industrial and service cooperatives-CECOP 2013)

Legacoop Tourism is a huge sector organization affiliated to Legacoop, the largest national cooperative structure in Italy. Legacoop Tourism has more than 350 associated cooperatives (Vocatch 2010, p. 5). However, in India (as elsewhere), there is evidence suggesting that the role of participatory and community based organizations like cooperatives for purposes of tourism is still weak (Verma n.d.). Drawing from Asia, Verma (n.d.) observed that cooperatives can be found in various sectors of the economy and leveraging on their participatory and people centered approaches, they can be useful vehicles to tackle the various socio-economic problems these countries are facing given the rapid growth of the tourism industry in that part of the world.

Different relationships between cooperatives and tourism have been created and observed so that the CBT approach has also been linked to cooperative enterprises (Saayman and Giampiccoli 2016). Importantly, it is noted that in CBT, community involvement is not enough, and that there is the need to go beyond merely involvement, thus requiring ownership and control of the tourism sector. People have to initiate, own, and control developments from the beginning to the end (going beyond mere involvement and participation) as forms of self-participation, and external parties should only assist them in their CBT ventures (Giampiccoli and Saayman 2018, p. 9).

The coop business model also focuses on the control and ownership by its workers/members. In this case, it is a matter of valorizing the advantages of CBT and those of the cooperatives. Some advantages of this combination include the involvement of many people who benefit from the profit generated, limited liability of members, and the potential of management to be professionalized. The disadvantages are that decision-making usually requires a longer time, control of the business is shared (dissipated) 
among members, and processes can be bureaucratic (Calanog et al. 2012, p. 302). Besides CBT, there are other examples that can be instrumental to understanding cooperatives in tourism and hospitality.

For example, in Bulgaria, 'The Central Cooperative Union boasts the ownership of six hotel complexes, six guest houses, and a specialized rehabilitation hospital in the town of Bankya and is modernizing and renovating them to meet the needs of their customers in which members and their families enjoy special packages and preferential treatment in these businesses (Central Cooperative Union, Bulgaria n.d.). Cooperative entities also extend the potential of holidaying to people that otherwise would not be able to afford it. The fact that cooperatives do not only focus on profit implies that they can have better (cheaper) offers for their members or other customers. This is certainly important as it serves to increase equality in society and allows for many, especially the disadvantaged, to go on holiday, as holidaying should not only be a preserve of the wealthy sections of society. Sceptics could argue that this could be their weakness as they charge uneconomic rates that lead to their bankruptcy. The counter-argument is that the equalizing and democratizing socio-economic opportunities such as holidaying do more common good for the welfare of communities that cannot be measured in monetary terms.

Experiences from India have shown links between tourism cooperatives and peace building. This was done on the understanding that one of the foundation pillars of cooperatives is peace. For Verma (n.d.), cooperatives are value-based and are capable of spreading peace through tourism. Nevertheless, "instances of cooperatives involved in tourism are negligible, the Indian cooperatives have strong potentialities to emerge as a lead player in the field of tourism [ ... ]. A review of the cooperative trends in the recent times indicate that cooperatives are aware to diversity in new areas like tourism." (Verma n.d.). The Indian Government is mooting the idea of rural tourism steeped in cooperatives as the cooperatives "cover 100\% of the villages in the country" (Vocatch 2010, p. 6). Government is important, but often regulation is shifted to voluntary measures by private sector lobbyists to introduce codes of conduct and pursue corporate social responsibility (CSR) functions. Codes of conduct and CSR are weak and industry friendly without any real potential to change the structures of the tourism sector for social justice if they are not legally enforced (Saayman and Giampiccoli 2016, p. 161). For instance, looking at a PPT context as an alternative tourism approach, Schilcher (2007) mentions that CSR and codes of conduct are a form of 'pro-poor tourism' (PPT) supported by neoliberalism in which governments are told to not interfere with market forces, thus abrogating poverty alleviation to the private sector. Using codes of conduct and self-regulation, some accommodation establishments may be happy to provide donations to some community cause, but unwilling to uphold effective labor rights "rather than making long term changes so that their practices including employment, training and procurement, are more pro-poor" (Scheyvens 2007, p. 140). In such a context, the need for a strong government that regulates and enforces legislation is fundamental and the same government should be instrumental in facilitating and supporting the cooperative model as a way to intrinsically reconfigure the tourism sector into a more just, equitable, and sustainable economic sector. Cooperatives have the potential to drive a development trajectory that delivers a just tourism. We define just tourism as a form of tourism that delivers the most benefits to its members-for themselves and by themselves-representing a form of accumulation from within. Just tourism must also be intrinsically linked to, and benefit the local context (such as where the coop is based and or is operating).

The Casa Nueva restaurant (which is Mexican) in Athens, Ohio, USA has survived for more than thirty years (Dastur 2012, p. 17). More specifically, the Casa Nueva website (Casa Nueva n.d.) indicates: "We are very proud to have been a provider of local, sustainable, Mexican-inspired food for our community for the last 30+ years!" Flexibility on ownership and management structure (see Figure 1) and requirements is also recognized at the coop level. For example, Casa Nueva restaurant declares that their "success as a cooperative rests firmly on our ability to adapt these [other cooperatives] models to the goals and needs of the business and the individual co-op members." (Casa Nueva n.d.). At Casa Nueva, every worker has a voice, is listened to, and also accorded due respect; worker-owners have the prerogative to vote, as every worker-owner has one non-transferable share of the business 
that accords them one vote, and people are accountable for the decisions they make (Casa Nueva n.d.). Figure 1 shows the management structure of the Casa Nueva restaurant.

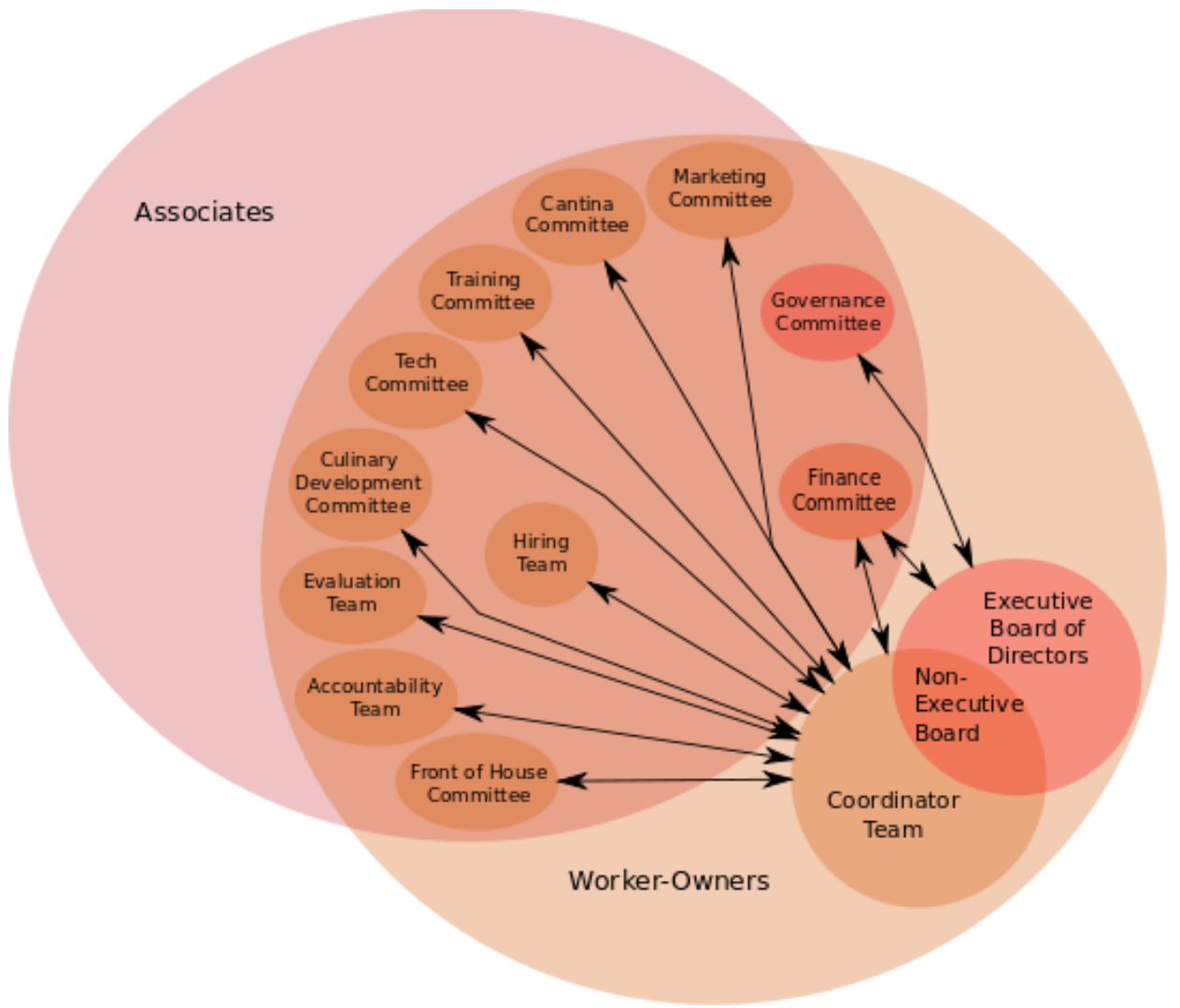

Figure 1. Ownership and management structure of Casa Nueva restaurant. Source: (Casa Nueva n.d.).

The Casa Nueva restaurant seems to be very proud of their status as a worker cooperative as the words 'worker owned' are clearly visible in their logo (see Figure 2). This is an important matter as WCs have the potential to promote self-esteem and pride in their workers.

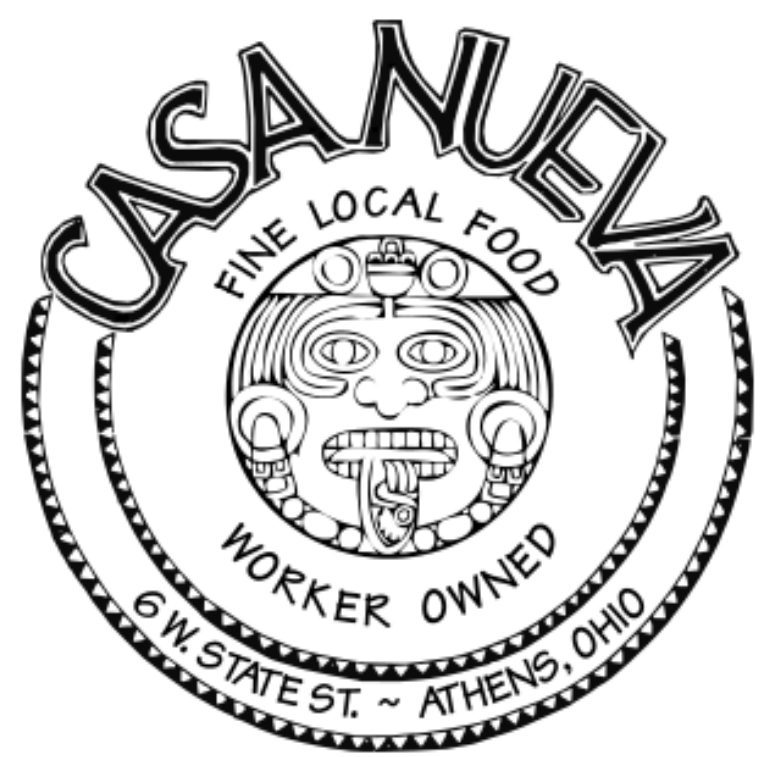

Figure 2. Logo of Casa Nueva restaurant. Source: (Casa Nueva n.d.). 
The last example is from Cuba. It is relevant in showing that cooperatives, with the proper legal and supportive institutions, can work anywhere. The Cuban Government, in a quest to "update its Socialism" has released some of its assets into the hands of cooperatives. A good example is the La Casona Restaurant Cooperative, which is made up of 46 workers. They run the operations of the restaurant and share its profits. The restaurant was previously owned by the Ministry of Tourism and the workers formed themselves into a cooperative (Bachtell 2015). While there have been cooperatives in Cuba since 1959 (mostly in agriculture), new economic and social guidelines adopted in 2011 provide the basis upon which the major restructure of the Cuban economy took place. The new guidelines promote cooperatives, especially in the services sector. In 2015, there were 500 non-agricultural cooperatives with about 10,000 workers under their employ in the food and retail sectors and the number was expected to reach 3000 in 2015 with property being loaned by the state for empowerment (Bachtell 2015). However, in Cuba, the laws governing cooperatives do not allow for the accumulation of capital and disallow the formation of franchises (Bachtell 2015). The next section presents a model of a just tourism sector.

\section{Towards a Model for Just Tourism}

The literature reviewed above shows the value of the cooperative sector and its potential. Of note are its principles and parameters of operations, which are also in line with CBT, that drive toward a more just and equitable tourism sector. There are cooperative enterprises in the tourism sector however small their number may be. We argue that cooperatives do matter if the objective is to reach out to large numbers of community members for redress and justice. This will be possible in circumstances were tourism is a major contributor to a country's GDP and when cooperative enterprises in the sector take control of a large size of the tourism industry through scaling up. Thus, the aim is to go beyond the single enterprise to build a franchise/network of cooperatives that produce a linked system of enterprises (hotels in this example) to drastically increase the footprint, value, and weight of cooperatives in the tourism sector. This article posits such a model in Figure 3 for tourism with specific reference to the accommodation sector. We call this the coop hotels model.

The intention of the 'coop hotels model' is to increase the footprint of the cooperative enterprises where workers are owners of the hotels. We added a caveat where it is possible for the worker-owners to work together with external partners (with specific limitations). Each coop hotel can, individually or in a group, formally link with other cooperatives in the tourism sector such as a travel agent cooperative, tour operator cooperatives, restaurant cooperative, and so on. In this way, each coop hotel will have a certain level of independence, although group association is encouraged.

For simplification, a hotel was used as a type of establishment, but any type of accommodation (hotel, lodge, resort, campsite, and so on) can be part of the coop system. This does not preclude the development of specific coop brands of a specific accommodation type. In other words, each coop hotel can have its own name for branding and marketing where the hotel can use its own brand and its own theme. A sister branding/marketing coop could work for all coops under the 'franchise' for the overall branding, marketing, and associated functions. The specific roles and functions of the sister coops should be flexible and negotiable. For example, a coop could assume the function of booking and work as a travel agency for the coop system. The possibilities are wide. 


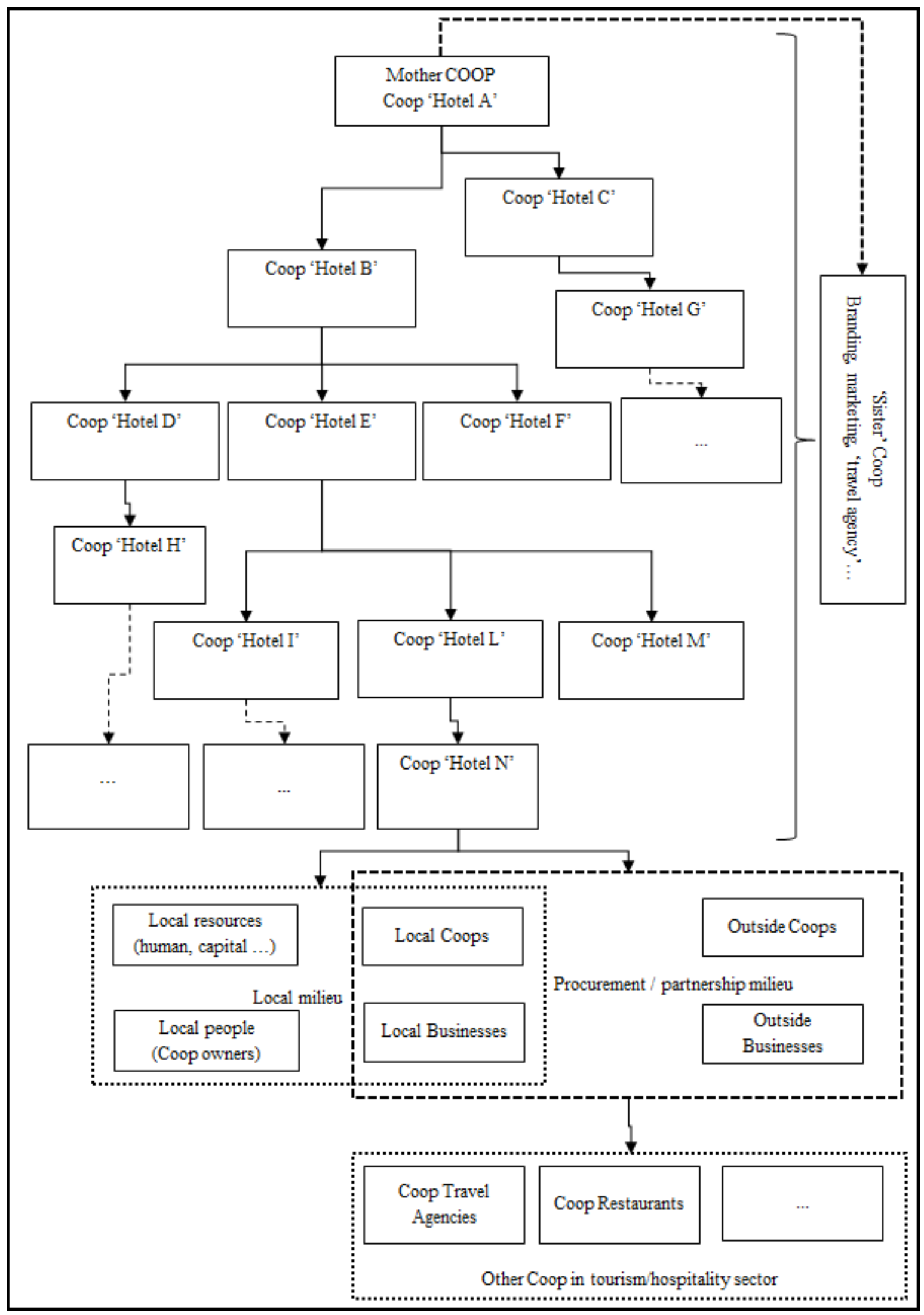

Figure 3. Coop hotel model. Authors' elaboration. 
Besides the general cooperative principles and 'rules' that should be the underlying parameters underlying the functions of these cooperatives, the coop hotels are envisaged to embrace the WC system and focus on its embedment, taking into account the local contexts and its vanguard role as a promoter of redistribution and community development. In this vein, the important features of the coop hotels system should include:

- Worker ownership. People working in the coop should be the first to own the cooperative. Ideally, coop workers should own at least $51 \%$ of the coop to guarantee that they retain control of their own business (coop workers owning 51\% should also be a local resident).

- Local ownership. Besides worker ownership, the coop should favor local development, therefore, it should remain locally based and controlled. Ideally, the coop should be $100 \%$ locally owned. It is possible that this requirement will not be met in all circumstances. Therefore, it should be a must, as much as possible, that at least $51 \%$ of ownership must be held by local people and/or permanent residents (who must live there and not reside elsewhere in the world). This will guarantee greater local control of the coop hotel.

- All procurement should follow the following preferential criteria: (1) goods and services should be procured from other local coops; (2) from local businesses; (3) outside coops, and (4) from outside businesses. Coops should be prioritized and favored as a matter of principle in order to promote local development. Small businesses will also be prioritized over large businesses of multinational corporations as much as possible. Sister coops should play a key role so that all procurement can leverage better prices for all coops under the system. Local coops and small businesses should be favored as the basis for making procurement decisions.

- Use of local human resources. Preference should be given to local human resources. If not available, establish educational/training programs to develop an appropriate local skills base. This does not mean to exclude tout court non locals from working in the coop hotel, but it is important to give priority to local people where possible. Nonlocal capacity is welcome for diversity as they can contribute positively with their experiences, different cultural backgrounds, and skills.

- Use of local capital and financial resources. It is important that local capital and financial resources are the sources to fund the coop hotels. This serves to keep local control of the hotels.

It is of cardinal importance for the coop hotels to be solidly anchored and embedded in the local area and society. Anchored on procurement, Figure 3 shows that coop hotel ' $\mathrm{N}$ ' favors the local context for any possible coop hotel requirements and needs. Local ownership by local people further makes the coop hotel embedded in the local context. Worker cooperatives ensure the creation of community wealth undergirded by local ownership, they bestow the power to decide on key issues and increase the urgency in members to preserve the environment and allow the hiring of locals and cooperate with other businesses and reinvest profits in the community (SELC and East Bay Community Law Center(2016, p. 3).

As a matter of principle, a cooperative enterprise should be sustainable and serve its people/community. Hence, "cooperatives work for the sustainable development of their communities through policies approved by their members." (ICA n.d.). Tourism takes place in communities, cities, towns, villages, and many other places amongst people and environments in diverse ways. It influences all people. It is logical that the people upon which tourism impacts must be the ones who control it.

While the initial mother coop (Coop ' $A$ ') may be based on a specific location, its network can be locally based and may also be spread in other geographical areas. This implies that any coop hotel can become a mother coop of other coop hotels. Specific links need to be established with other coops in the tourism and hospitality sectors to try to increase the weight and control of the sector itself.

Within the general rules and requirements provided by the mother coop hotel (Hotel A), it is important that the constitution of the coop hotel system allows each coop hotel to adopt specific policies and regulations regarding ownership and management structures as each local context may have its own needs and requirements. The maintenance of a proper network and linkages 
amongst the various coop hotels is important. Cooperative networks are key. For example, to mark the importance of networks, in 1966, the idea of cooperation among cooperatives was one of the Seven Cooperative Principles (OECD LEED 2014, p. 59). In this context, the model proposed here supports that each coop hotel is a single entity with a respective mother coop going up to the scale. This allows for each individual person/member (as a part of the entity) to belong to the 'entire' network. Hotel accommodation, contrary to other economic sectors, is very distributed on global scale-as you can find small hotels or some form of accommodation in small villages-thus this shows the potential available to spread the coop hotel model. Thus, a network of coop hotels (which can involve any type of accommodation) can greatly increase its footprint and weight in the tourism and hospitality sector.

This article argues that when employees and local communities have control and enjoy the benefits from a local hotel (and by extension, the tourism sector), chances are that their support and buy-in is secured. While it might be difficult to establish this coop system in the short term, middle ground solutions can be implemented step by step with the ultimate goal being the establishment of the coop hotels for justice, hence we consider this model as ushering a novel system of hotels for just tourism. This article argues that tourism can bring about justice and equality if the cooperative model, that reflects the CBT model, is implemented in its essence.

\section{Conclusions}

In the contemporary neoliberal milieu, global inequality between and within countries is growing. Tourism is one of the leading economic sectors with specific impacts on local populations where the tourism activities happen. The sector is still largely embedded in a neoliberal discourse as other tourism development alternatives struggle to escape from the neoliberal milieu. Within this context, this paper proposes to advance the cooperative model in the tourism sector. Cooperatives are often undervalued. However, their role and significance in society is vast. Previous studies did not make a synthesis of CBT qualities and those of cooperatives. This is what makes the contribution unique. For management, the application of the model, which is proposed in this paper, transcends the tourism sector. In other words, it is possible to create mother coops, sister coops and child coops in the agro-processing industry or in any other sector, however, taking cognizance of the finer qualities from CBT and cooperatives. This article has shown that similar to CBT, the cooperatives' principles and characteristics are valuable toward the establishment of a more just and equal society. This article suggests that a reconfiguration of industry and economic sector structures is necessary to deliver just tourism. In other words, current systems undergirded by neoliberalism have failed to deliver jobs, equity, and social justice. Leveraging on the fine qualities found in cooperatives and by combining them with those from CBT, the article argues for a new pathway or trajectory with potential to drive the agenda for jobs, equity, and social justice. When crafting new policies for enterprise development, qualities such as local and worker ownership, community participation, and the use of local human resources should be taken into account, favored, infused, or embedded in those policies.

Based on the above, the article presented model of coop hotels, which serves as an example of how the cooperatives could increase their footprint in the tourism system and contribute to a shift toward a tourism industry that is egalitarian and just. This model does not purport to solve all problems linked to tourism development. It aims to advance a tourism development model (using the accommodation sector as an example) that can contribute, through its redistributive aspect, local control embedment, procurement processes, and adherence to the general principles of cooperatives, a tourism sector skewed toward social justice and equality. This article ends with hopeful remarks from previous research:

This vision of economic democracy-with cooperatives at the center, supplemented by an interventionist state and a public system of finance-has enormous transformative potential. It has such potential because each aspect of this reform program is imminently feasible [ ... ]. (Malleson 2010, p. 167) 
Beyond the proposed model, whatever type of an alternative that is taken in tourism development, the urgent need is the reconciliation, affirmation, and practical implementation of a major shift where the local community (especially the disadvantaged strata of society) take control of tourism development in their own area in a democratic and egalitarian society. Only in this way, can the tourism sector, as a major contributor to the global economy, can weigh in with greater relevance and an expanded role to contribute to a more just and equal world and society.

Author Contributions: The two authors worked together in the conceptualization and writing of the article. All authors have read and agreed to the published version of the manuscript.

Funding: This research received no external funding.

Conflicts of Interest: The authors declare no conflicts of interest.

\section{References}

Aref, Fariborz, and Sarjit S. Gill. 2009. Rural Tourism Development through Rural Cooperatives. Nature and Science 7: 68-73.

Bachtell, John. 2015. Cuba's Worker Cooperatives: “We Decide What to Do Here”. Peoples' World. Available online: http://www.peoplesworld.org/article/cuba-s-worker-cooperatives-we-decide-what-to-do-here/ (accessed on 27 June 2017).

Bianchi, Raoul V. 2002. Toward a New political Economy of Global Tourism. In Tourism and Development Concepts and Issues, 2nd ed. Edited by Richard Sharpley and David J. Telfer. Clevedon: Channel View Publications, pp. 265-99.

Bianchi, Raoul V. 2009. The 'Critical Turn' in Tourism Studies: A Radical Critique. Tourism Geographies 11: 484-504. [CrossRef]

Boden, Mark. 2011. Neoliberalism and Counter-Hegemony in the Global South: Reimagining the State. In Social Movements in the Global South: Dispossession, Development and Resistance, 1st ed. Edited by Sara C. Motta and Nilsen Alf Gunvald. New York: Palgrave Macmillan, pp. 83-103.

Borda-Rodriguez, Alexander, and Hazel J. Johnson. 2015. Reshaping Inclusive Development? The Case of Cooperative Enterprises. IKD Working Paper 79: 2-31. Milton Keynes: The Open University.

Borzaga, Carlo, Sara Depedri, and Ermanno Tortia. 2009. The Role of Cooperative and Social Enterprises: A Multifaceted Approach for an Economic Pluralism. Euricse Working Papers N. 00009. Rome: European Reseacrh on Cooperative and Social Enterprises, pp. 1-20.

Braun, Yvonne A., and Leslie A. McLees. 2012. Space, ownership and inequality: Economic development and tourism in the highlands of Lesotho. Cambridge Journal of Regions, Economy and Society 5: 435-49. [CrossRef]

Britton, Stephen G. 1991. Tourism capital and place: Towards a critical geography of tourism. Environmental and Planning 9: 451-78. [CrossRef]

Calanog, Lope A., Donna Paz T. Reyes, and Vincent F. Eugenio. 2012. Making Ecotourism Work. In A Manual on Establishing Community-based Ecotourism Enterprise (CBEE) in the Philippines. Makati City: Japan International Cooperation Agency.

Casa Nueva. n.d.a. About Us. Available online: http://casanueva.com/about-us/our-story/ (accessed on 28 June 2017).

Casa Nueva. n.d.b. Co-op \& Governance. Available online: http://casanueva.com/about-us/co-op-governance/ (accessed on 28 June 2017).

CECOP. 2013. Cooperatives Contribute Significantly to Sustainable Tourism in Europe. Available online: http://www.cecop.coop/Cooperatives-contribute (accessed on 29 June 2017).

Central Cooperative Union, Bulgaria. n.d. Tourism. Available online: https://www.cks.bg/en/turizum/ (accessed on 27 June 2017).

Chok, Stephanie, Jim Macbeth, and Carol Warren. 2007. Tourism as a Tool for Poverty Alleviation: A Critical Analysis of 'Pro-Poor Tourism' and Implications for Sustainability. Current Issues in Tourism 10: 144-65. [CrossRef]

Cole, Stroma, and Nigel Morgan. 2010. Introduction: Tourism and inequalities. In Tourism and Inequality: Problems and Prospects. Edited by Stroma Cole and Nigel Morgan. Oxford: CABI, pp. xv-xxiii. 
Cox, R.W. 1996a. Social forces, states and world orders: beyond international relation theory. In Approach to World Order. Edited by R.W. Cox and T.J. Sinclair. Cambridge: Cambridge University Press, pp. 85-123.

Cox, R.W. 1996b. Gramsci, hegemony and international relations: an essay in method. In Approach to World Order. Edited by R.W. Cox and T.J. Sinclair. Cambridge: Cambridge University Press, pp. 124-43.

Dastur, Nina K. 2012. Understanding Worker-Owned Cooperatives. A Strategic Guide for Organizers. Washington, DC: Center for Community Change.

Davolio, Maurizio. 2013. The identity of cooperative in tourism. Paper presented at Cit2013 Conference on Innovation in Tourism and Hospitality, Valencia-Benidorm, Spain, April 19.

de Kadt, E. 1979. Social planning for tourism in the developing countries. Annals of Tourism Research 6: 36-48. [CrossRef]

Devine, Pat. 2002. Building Socialism Theoretically: Alternatives to Capitalism and the Invisible Hand. Science $\mathcal{E}$ Society 66: 6-5.

Dugger, William M. 1987. Democratic Economic Planning and Worker Ownership. Journal Of Economic Issues XXI: 87-99. [CrossRef]

Elliot, John E. 1987. Karl Marx: Founding father of workers' self-governance? Economic and Industrial Democracy 8: 293-321. [CrossRef]

Eraqi, Mohammed I. 2007. Local communities' attitudes towards impacts of tourism development in Egypt. Tourism Analysis 12: 191-200. [CrossRef]

Eshliki, Sajad Alipour, and Mahdi Kaboudi. 2012. Community Perception of Tourism Impacts and Their Participation in Tourism Planning: A Case Study of Ramsar, Iran. Procedia - Social and Behavioral Sciences 36: 333-41. [CrossRef]

Fields, Z. 2011. Efficiency and Equity. The Empresas Recuperadas of Argentina. Latin American Perspectives 163: 83-92.

Fletcher, Robert. 2011. Sustaining tourism, sustaining capitalism? The tourism industry's role in global capitalist expansion. Tourism Geographies 13: 443-61. [CrossRef]

Giampiccoli, Andrea. 2007. Hegemony, Globalization and Tourism Policies in Developing Countries. In Tourism and Politics: Global Frameworks and Local Realities. Edited by Peter M. Burns and Marina Novelli. Oxford: Pergamon, pp. 175-91.

Giampiccoli, Andrea, and Oliver Mtapuri. 2012. Community-based tourism: An exploration of the concept(s) from a political perspective. Tourism Review International 16: 29-43. [CrossRef]

Giampiccoli, Andrea, and Oliver Mtapuri. 2017. Beyond Community-based tourism. Towards a new tourism sector classification system. Gazeta de Antropología 33: 1-14.

Giampiccoli, Andrea, and Melville Saayman. 2014. Conceptualisation of Alternative Forms of Tourism in Relation to Community Development. Mediterranean Journal of Social Sciences 5: 1667-77. [CrossRef]

Giampiccoli, Andrea, and Melville Saayman. 2016. Community-based tourism: From a local to a global push. Acta Commercii 16: 1-10. [CrossRef]

Giampiccoli, Andrea, and Melville Saayman. 2018. Community-based tourism development model and community participation. African Journal of Hospitality, Tourism and Leisure 7: 1-27.

Gilson, Lucy L., and Caren B. Goldberg. 2015. So, What Is a Conceptual Paper? Group E Organization Management 40: 127-30.

Gosovic, Branislav. 2000. Global intellectual hegemony and the international development agenda. International Social Science Journal 52: 447-56. [CrossRef]

Hall, Stuart, Doreen Massey, and Michael Rustin. 2015. Framing statement. After neoliberalism: Analysing the present. In After Neoliberalism: The Kilburn Manifesto. Edited by Hall Stuart, Doreen Massey and Michael Rustin. London: Soundings, pp. 9-23.

Head, J. 2020. Coronavirus: Tourism in Thailand hit by Covid-19. BBC News. March 13. Available online: https://www.bbc.com/news/business-51796812 (accessed on 16 March 2020).

Higgins-Desbiolles, Freya. 2008. Justice Tourism and Alternative Globalisation. Journal of Sustainable Tourism 16: 345-64. [CrossRef]

Hunter Wade, R. 2004. 'Is Globalization Reducing Poverty and Inequality?'. World Development 32: 567-89. [CrossRef]

ICA. n.d.a. Co-Operative Facts \& Figures. Available online: http://ica.coop/en/whats-co-op/co-operative-factsfigures (accessed on 4 July 2017).

ICA. n.d.b. Co-Operative Identity, Values \& Principles. Available online: http://ica.coop/en/whats-co-op/cooperative-identity-values-principles (accessed on 1 July 2017). 
Ife, Jim. 2002. Community Development: Community-Based Alternative in the Age of Globalisation. Sydney: Pearson Education. Jaafar, Mastura, Safura Ismail, and S. Mostafa Rasoolimanesh. 2015. Perceived Social Effects of Tourism Development: A Case Study of Kinabalu National Park. Theoretical and Empirical Researches in Urban Management 10: 5-20.

Ji, Minsun. 2014. Hotel Bauen Worker Cooperative Faces Eviction. The Argentinian Independent. Available online: http://www.argentinaindependent.com/socialissues/hotel-bauen-worker-cooperative-faces-eviction/ (accessed on 27 June 2017).

Kotz, David M. 2008. What Economic Structure for Socialism? Paper presented at the Fourth International Conference "Karl Marx and the Challenges of the XXI Century", Havana, Cuba, May 5-8.

Krajnović, Aleksandra, Anita Radman Peša, and Jurica Bosna. 2015. The Model of Eastern Croatia Rural Tourism Development Based on the Example of Austria. Economy of Eastern Croatia-Yesterday, Today, Tomorrow 4: 78-88.

Lebowitz, Michael A. 2004. Ideology and Economic Development. Monthly Review 56: 14-24. [CrossRef]

Ly, Tuan Phong. 2014. Commercialization and sanitation: Critical issues in allowing locals to inhabit the core zone of a national park. A case study of Phong Nha-Ke Bang National Park in Vietnam. In Rethinking Asian Tourism: Culture, Encounters and Local Response. Edited by Ploysri Porananond and Victor T. King. Newcastle upon Tyne: Cambridge Scholars publishing, pp. 247-65.

Malleson, Tom. 2010. Cooperatives and the 'Bolivarian Revolution' in Venezuela. Affinities: A Journal of Radical Theory, Culture, and Action 4: 155-75.

Manuel-Navarrete, D. 2012. Entanglements of Power and Spatial Inequalities in Tourism in the Mexican Caribbean. desiguALdades.net Working Paper Series, No. 17; Berlin: desiguALdades.net Research Network on Interdependent Inequalities in Latin America, Available online: https://www.desigualdades.net/Working_Papers/ Search-Working-Papers/Working-Paper-17-_Entanglements-of-Power-and-Spatial-Inequalities-in-Tourism-inthe-Mexican-Caribbean_/index.html (accessed on 20 February 2020).

Mazzarol, Tim. 2009. Cooperative Enterprises. A Discussion Paper E Literature Review. Perth: Co-operatives WA.

McClendon, Robert. 2014. New Orleans' Tourism Industry Booms but Income Inequality Remains Entrenched. Available online: http://www.nola.com/politics/index.ssf/2014/10/new_orleans_tourism_industry_b.html (accessed on 20 February 2020).

McNamara, John. 2017. Stand in Solidarity with Hotel Bauen Workers. Appeal for International Solidarity with the Law of Expropriation of the Hotel Bauen Voted by the Argentine Congress on November 30th, 2016 and Vetoed by President Mauricio Macri. The Workers' Paradise. Available online: http://www.cooperativeconsult.com/ 2017/01/27/stand-in-solidarity-with-hotel-bauen-workers/ (accessed on 27 June 2017).

Mills, Cliff, and Will Davies. 2013. Blueprint for a Co-Operative Decade. Brussels: InternatIonal Co-operatIve Alliance.

Mohamad, Nor Haniza, and Amran Hamzah. 2013. Tourism cooperative for scaling up community-based tourism. Worldwide Hospitality and Tourism Themes 5: 315-28. [CrossRef]

Mosedale, Jan. 2016. Neoliberalism and the political economy of tourism: Projects, discourses and practices. In Neoliberalism and the Political Economy of Tourism. Edited by Jan Mosedale. New York: Routledge, pp. 1-20.

Mowforth, Martin, and Ian Mun. 2003. Tourism and Sustainability. Development and new tourism in the Third World, 2nd ed. London: Routledge.

Nyerere, Julius K. 1974. Ujama Essay on Socialism. Dar es Salaam: Oxford University Press.

OECD LEED. 2014. The Co-Operative model in Trentino-Italy. A Case Study. Paris: OECD LEED.

Olsen, Erik K. 2013. The Relative Survival of Worker Cooperatives and Barriers to Their Creation. Advances in the Economic Analysis of Participatory E Labor-Managed Firms 14: 83-107.

Peet, Richard. 2002. Ideology, Discourse and the Geography of Hegemony: From Socialist to Neoliberal Development in Postapartheid South Africa. Antipode 34: 54-84. [CrossRef]

Pleumaron, Anita. 2012. The Politics of Tourism, Poverty Reduction and Sustainable Development. Penang: Third World Network.

Reye, Julie A. 2011. The roles of sustainable tourism in neoliberal policies and poverty reduction strategies: Do they adequately address quality of life? The Applied Anthropologist 31: 23-29.

Saayman, Melville, and Andrea Giampiccoli. 2016. Community-based and pro-poor tourism: Initial assessment of their relation to community development. European Journal of Tourism Research 12: 145-90.

SAF-South African Foundation. 2003. Co-Operatives in South Africa: Their Role in Job Creation and Poverty Reduction. Occasional paper No2/2003. Johannesburg: South Africa Foundation. 
Salleh, Norlida Hanim Mohd, Mohd Shafiin Shukor, Redzuan Othman, Mohd Samsudin, and Siti Hajar Mohd Idris. 2016. Factors of Local Community Participation in Tourism-Related Business: Case of Langkawi Island. International Journal of Social Science and Humanity 6: 565-71. [CrossRef]

Scheyvens, Regina. 2007. Exploring the Tourism-Poverty Nexus. In Pro-Poor Tourism: Who Benefits? Perspective on Tourism and Poverty Reduction. Edited by Michael Hall. Clevedon: Channel View Publications, pp. 121-44.

Schilcher, Daniela. 2007. Growth versus equity: The continuum of pro-tourism and neoliberal governance. In Pro-Poor Tourism: Who Benefits? Perspective on Tourism and Poverty Reduction. Edited by Michael Hall. Clevedon: Channel View Publications, pp. 56-83.

SELC (and East Bay Community Law Center, Green-Collar Community Clinic). 2016. Think Outside the Boss: How to Create A Worker-Owned Business. Oakland: Sustainable Economics Law Center, East Bay Community Law Center, Green-Collar Community Clinic.

Sharpe, Erin, Felice Yuen, and Heather Mair. 2016. Community Development in Leisure: Laying the Foundations. In Community Development Applications for Leisure, Sport, and Tourism. Edited by Erin Sharpe, Heather Mair and Felice Yuen. Urbana: Venture Publishing, pp. 3-14.

Su, Ming Ming, and Geoffrey Wall. 2014. Community Participation in Tourism at a World Heritage Site: Mutianyu Great Wall, Beijing, China. International Journal of Tourism Research 16: 146-56. [CrossRef]

Tewari, Dev. D. 2011. Wealth creation through mass capital mobilization through a cooperative enterprise model: Some lessons for transplanting the Indian experience in South Africa. African Journal of Business Management 5: 8980-89.

Titzler, Bryan. 2016. Worker Cooperatives as an Innovative Strategy to Address Income Inequality? Stevenson Center for Community and Economic Development-Student Research. p. 18. Available online: https: //ir.library.illinoisstate.edu/scced/18/ (accessed on 20 February 2020).

Tosun, Cevat. 2000. Limits to community participation in the tourism development process in developing countries. Tourism Management 21: 613-33. [CrossRef]

UN. n.d. About Cooperatives. Available online: https://social.un.org/coopsyear/cooperatives-are.html (accessed on 27 June 2017).

United States Federation of Worker Cooperatives. 2007. What Is a Worker Cooperative? Available online: http://www.uwcc.wisc.edu/pdf/What\%20is\%20WC.pdf (accessed on 27 June 2017).

UNWTO. 2020a. TOURISM AND CORONAVIRUS DISEASE (COVID-19). Available online: https://unwto.org/ tourism-covid-19-coronavirus (accessed on 16 March 2020).

UNWTO. 2020b. COVID-19: UNWTO CALLS ON TOURISM TO BE PART OF RECOVERY PLANS. Available online: https://www.unwto.org/news/covid-19-unwto-calls-on-tourism-to-be-part-of-recoveryplans (accessed on 16 March 2020).

Verma, Sanjay Kumar. n.d.a. Cooperatives and Tourism: An Asian Perspective. Available online: http: //torc.linkbc.ca/torc/downs1/india\%20cooperatives.pdf (accessed on 28 March 2013).

Verma, Sanjay Kumar. n.d.b. Promoting Peace through Tourism: Role of Cooperatives. Available online: http://www.iipt.org/3rdglobalsummit/presentations/Sanjay-Kumar-Verma-presentation.htm (accessed on 27 June 2017).

Vocatch, Igor. 2010. ILO and cooperative tourism: Challenges and statistical measurement. Paper presented at Regional Workshop for the CIS countries "Developing National Systems of Tourism Statistics: Challenges and Good Practices", Chisinau, Moldova, June 29-July 2; Available online: https:/unstats.un.org/Unsd/tradeserv/Workshops/ Chisinau/docs/10\%20b\%20-\%20ILO\%20and\%20cooperative\%20tourism.pdf (accessed on 23 June 2017).

Wearing, Stephen L., and Michael Wearing. 2016. Decommodifying Grass Roots Struggle Against a Neoliberal Tourism Agenda: Imagining a Local, Just and Sustainable Eco-tourism. In Neoliberalism and the Political Economy of Tourism. Edited by Jan Mosedale. New York: Routledge, pp. 139-56.

Williams, Raymond. 1976. Base and superstructure in Marxist cultural theory. In Schooling and Capitalism. A Sociological Reader. Edited by Roger Dale, Geoff Esland and Madeleine MacDonald. Maidenhead: The Open University Press, pp. 202-10.

Zajda, Joseph. 2011. Globalisation and schooling: Equity and access issues. Cultural Studies of Science Education 6: 143-52. [CrossRef]

(C) 2020 by the authors. Licensee MDPI, Basel, Switzerland. This article is an open access article distributed under the terms and conditions of the Creative Commons Attribution (CC BY) license (http://creativecommons.org/licenses/by/4.0/). 